\title{
FROM THE HISTORY OF UZBEK-KOREAN CULTURAL RELATIONS
}

\author{
Fazilat Ilkhomovna Nurmetova \\ Teacher the department of "Theory of civil society" of Andizhan State University named after Babur, \\ Andizhan region, Republic of Uzbekistan
}

Article DOI: https://doi.org/10.36713/epra8128

DOI No: 10.36713/epra8128

\begin{abstract}
This article provides a detailed analysis of the history of Uzbek-Korean cultural relations in the Commonwealth and its further development with the help of Internet data and sources. Research also gives latest information about the head of state also met with the Speaker of the National Assembly and the Prime Minister of the Republic of Korea and took part in the Uzbek-South Korean business forum with the participation of leaders of leading economic and financial structures of the two countries.
\end{abstract}

KEY WORDS: Cooperation, Uzbekistan, Korea, contracts and agreements, strategic partnership, Korean cultural centers, innovation.

\section{INTRODUCTION}

It should be noted that the peoples of Uzbekistan and the Republic of Korea are bound by centuries-old friendship and ties that continue to this day. This goes back a long way. It should be noted that on the walls of the ancient city of Afrosiab, located in the territory of modern Samarkand, there are paintings depicting the visit of ambassadors of the Korean Goguryeo dynasty in the VII century.

\section{METHODS}

During the years of independence, Uzbekistan has paid special attention to ways to carry out structural changes in the economy to stabilize the macro economy, to build enterprises capable of producing competitive goods and to allocate the necessary investments. At the same time, one of the main directions of the foreign policy of the republic is the establishment of international relations with countries around the world. Following this goal, he said we will continue the large-scale work we have begun to intensify Uzbekistan's foreign policy, an open, pragmatic and well-thought-out foreign policy that meets our national interests. We will further strengthen cooperation, long-term and multifaceted partnership with all countries, far and near. I would like to draw your attention to the following priorities in this regard. The second priority is to further develop political, trade, economic, investment, transport and communication, cultural and humanitarian ties with South Korea, Turkey, the United Arab Emirates, the European Union and Asia President Mirziyoyev's address to the Oliy Majlis on January 24, 2020 [1].

\section{RESULTS AND DISCUSSIONS}

On November 22-25, 2017, President Shavkat Mirziyoyev paid a state visit to the Republic of Korea at the invitation of President Moon Jae-in. The high-level talks focused on a wide range of issues of cooperation, prospects for further development of interstate relations in political, trade, economic, financial, investment, scientific, technical, cultural, humanitarian and other spheres, as well as regional and international issues. The head of our state also met with the Speaker of the National Assembly and the Prime Minister of the Republic of Korea and took part in the Uzbek-South Korean business forum with the participation of leaders of leading economic and financial structures of the two countries. This historic visit has laid a solid foundation for the development of multifaceted ties. In his speech, the President noted that trade and economic relations between Uzbekistan and South Korea have been steadily developing, and modern conditions and opportunities for doing business have been created in our country. He noted that Uzbekistan is interested in further expanding 
cooperation with the business community of the Republic of Korea. The Republic of Korea proposed to establish a business center in Uzbekistan. Representatives of the South Korean financial and business circles praised the opportunities created for active business in Uzbekistan and expressed readiness to further develop cooperation. During the visit, more than 20 interstate, intergovernmental and interagency agreements were signed. A comprehensive study of these processes from a historical point of view is of scientific and practical importance today [2].

Although Uzbekistan and Korea are far from each other, they are bound by long-standing ties of friendship and mutually beneficial cooperation. There are similarities in the art, culture, national mentality and hard work of the two peoples. The Koreans who came to Uzbekistan and settled here have become friends with our people, and many of them have become prominent, prestigious and respected members of our society it is especially gratifying that they have made great strides in various fields and set an example for others. Our Korean compatriots are selflessly working in the Legislative Chamber and Senate of the Oliy Majlis, local councils, government agencies, science, culture and art, economic and social spheres. Many of them are well-known coaches who have won the highest awards of our country.

Nowadays, the relations between Uzbekistan and South Korea are developing on the basis of more than 170 agreements and treaties in various fields. Important documents such as the Joint Declaration on Strategic Partnership (2006), the Joint Declaration on Further Development and Deepening of Strategic Partnership (2014) in the political, trade, economic, investment, cultural and humanitarian spheres allowed to take bilateral relations to a qualitatively new level [3]. Economic relations between our countries are developing rapidly, and constructive and mutually beneficial political dialogue is becoming more active. The Republic of Korea is a leading technological partner in the implementation of priority programs for diversification and modernization of industry and infrastructure in our country.

First, the political relations between Uzbekistan and the Republic of Korea continue in the spirit of mutual support in the international arena. It is noteworthy that the approaches of the parties on issues of global and regional significance are similar or close. In particular, the UN General Assembly is successfully implementing initiatives and resolutions, supporting candidates for various UN bodies, and cooperating within regional structures in Asia.

At the invitation of President of the Republic of Uzbekistan Shavkat Mirziyoyev, President of the Republic of Korea Moon Jae-in arrived in our country on April 18, 2019 with a state visit. This historic visit has laid a solid foundation for the development of multifaceted ties. During the visit, more than 20 intergovernmental, intergovernmental and interdepartmental agreements were signed, as well as 64 documents worth more than $\$ 10$ billion [4]. It is no exaggeration to say that the state visit of the President of the Republic of Korea to Uzbekistan has served as an important event in the history of Uzbek-South Korean relations, bringing our countries and peoples closer.

Cooperation between the Republic of Uzbekistan and the Republic of Korea covers almost all areas. The most convenient mode of trade and also the Intergovernmental Commission on Trade and Economic Cooperation plays an important role in the development and implementation of mutually beneficial projects. In 2018, the format of the Deputy Prime Minister's Meeting on Economic Affairs was also introduced.

Uzbekistan and South Korea have been cooperating effectively in the fields of information technology, digital medicine, education and culture. The experience of South Korea is being widely introduced into the preschool education system of our country. The head of our state has developed exchange educational programs on the basis of agreements between Uzbekistan and Korea, opened branches of Korean higher education institutions in Uzbekistan, and created all conditions for the education of young people.

The Uzbek and Korean peoples have similar worldviews and traditions. Our countries have used each other in the most difficult times. Today, more than 180,000 Koreans living in Uzbekistan have become an integral part of our multi-ethnic society. The Association of Korean Cultural Centers has regional branches. The association is actively working to preserve and develop the Korean language, culture, customs and traditions in our country and abroad.

Our universities have established cooperation with more than 45 research institutions in South Korea. Branches of four universities of the Republic of Korea have been opened in our capital. Cooperation in the field of education is also expanding. Higher education institutions of our country have established cooperation with more than 30 research institutions of the Republic of Korea. Korean language and culture centers have been opened in a number of educational institutions. Speaking about cooperation in this area, it should be noted that in 2014, Inha University was opened in Tashkent. This higher education institution is the first foreign educational institution that makes a worthy contribution to the training of highly qualified IT specialists at the level of international standards. 
Today, the university has 1,078 students majoring in information technology, engineering and logistics.

Relationships are about innovation and of course progress. The history of Uzbekistan is the strongest basis for this. We believe that KoreanUzbek relations will rise to the level of innovation in the 21 st century and contribute to the common development of the two countries. The trade turnover between the two countries reached a record high of $\$ 2.1$ billion. The fact that more than 600 Korean companies operate in Uzbekistan testifies to the continuous expansion of ties and investments.

On January 28, 2021, President of the Republic of Uzbekistan Shavkat Mirziyoyev held a video conference with President of the Republic of Korea Moon Jae-in. It was noted that the multifaceted Uzbek-Korean relations, despite the pandemic, continue to develop steadily. Last year, the two leaders spoke by telephone twice and jointly attended the Second International Forum on Northern Economic Cooperation.

Agreements were reached on the continuation of regular political consultations and intensification of inter-parliamentary exchanges, the preparation of a program of bilateral events dedicated to the 30th anniversary of the establishment of diplomatic relations between our countries. The Presidents noted with satisfaction the growing number of branches of leading South Korean universities and joint training centers in the regions of Uzbekistan. Particular attention was paid to expanding the teaching of Uzbek and Korean languages in the leading higher education institutions of our countries, as well as to providing full support to the Korean diaspora.

\section{CONCLUSION}

The Presidents reaffirmed their determination to strengthen the ties of friendship and wide-ranging partnership, raise to a qualitatively new level of mutually beneficial cooperation for the benefit of our fraternal countries and peoples. The development of Uzbekistan is the development of Korea. Korea will definitely share its experience of economic development with Uzbekistan. Relations between the two countries are based on innovation and development. We draw the history of a new partnership on each other's walls. The fraternal relations between the two countries will forever be inherited by our generations.

\section{REFERENCES}

1. Address of the President of the Republic of Uzbekistan Sh. Mirziyoyev to the Oliy Majlis // https://www.gazeta.uz. 2020/01/24

2. www.kun.uz

3. www.strategy.uz

4. www.uzavtoyul.uz

5. www.adolatgzt.uz
6. www.old.xs.uz

7. https://uzsm.uz/ 